\title{
Breast Cancer cN3 TNM Finding v8
}

National Cancer Institute

\section{Source}

National Cancer Institute. Breast Cancer cN3 TNM Finding v8. NCI Thesaurus. Code C139404.

Breast cancer with metastases in ipsilateral infraclavicular (level III axillary) lymph node(s) with or without level I, II axillary lymph node involvement; or in ipsilateral internal mammary lymph node(s) with level I, II axillary lymph node metastases; or metastases in ipsilateral supraclavicular lymph node(s) with or without axillary or internal mammary lymph node involvement. (from AJCC 8th Ed.) 